\title{
Economic Development via Collaborating Populations
}

\author{
Dennis Ridley ${ }^{1,2}$ \\ ${ }^{1}$ School of Business and Industry, Florida A\&M University, Tallahassee, USA \\ ${ }^{2}$ Department of Scientific Computing, Florida State University, Tallahassee, USA \\ Email: dridley@fsu.edu
}

How to cite this paper: Ridley, D. (2021). Economic Development via Collaborating Populations. Theoretical Economics Letters, 11, 1101-1121.

https://doi.org/10.4236/tel.2021.116070

Received: October 9, 2021

Accepted: November 16, 2021

Published: November 19, 2021

Copyright (c) 2021 by author(s) and Scientific Research Publishing Inc. This work is licensed under the Creative Commons Attribution International License (CC BY 4.0).

http://creativecommons.org/licenses/by/4.0/

\begin{abstract}
Cooperation involves the integration of individual human efforts. When applied to a dyadic division of labor, production and trade, the most fundamental outcome is the unintentional mutual benefit of two parties. This is a fundamental tenet of economic growth through self-interest. Cooperation is manifest in various species in the animal kingdom. Collaboration opens the potential for innovation and the conversion of human capital imagination and creativity into new products and services, where mutual benefit is intentional. While cooperation is essential for ordinary economic growth, the path to extraordinary economic growth and development is collaboration $\rightarrow$ capitalization $\rightarrow$ gross domestic product $\rightarrow$ economic development. In economic development, consideration is given to both economic and social conditions. Collaboration is manifest in human beings and is responsible for superior development that would otherwise not be possible. It distinguishes the human species from all others.
\end{abstract}

\section{Keywords}

Collaboration, Innovation, Mental Silos, Cognitive Reintegration, Economic Development

\section{Introduction}

The terms collaboration and cooperation are sometimes confused. So are economic growth and economic development. In this research we are interested in collaboration and economic development based on epistemological, metaphysical, and axiological insights (Randrup, Druckemiller, \& Briggs, 2016), so for clarity of purpose, we begin with the following definitions.

Definition. Cooperation is a plan and execution thereof by participants work- 
ing together, each with their own personal self-interest and economic gain in mind yet yielding unintended mutual benefits.

Definition. Collaboration is a plan and execution thereof by participants working together for their intentional mutual benefit of shared goals, objectives, and rewards.

Definition. Economic growth is the improvement in per capita real gross domestic product adjusted for purchasing power parity.

Definition. Economic development is the improvement in infrastructure and social wellbeing.

\section{Wealth}

For wealth to exist, it must first be created. The source of wealth is human capital ideas of imagination and creativity. The creation process is epitomized by collaboration in the conversion of capital to per capita real gross domestic product (GDP) adjusted for purchasing power parity (GDPppp). GDPppp is a measure of standard of living, albeit not uniformly distributed. GDP is the value of all the products and services that an economy produces. After consumption, the remainder is a contribution to wealth. After that, it can be moved from person to person, community to community, economic sector to economic sector, and country to country. Simultaneously, wealth is dissipated by the mechanism of depreciation. If there is no reinvestment in the economy and no new human capital ideas, wealth will decline monotonically, eventually to zero.

\section{Creation}

The process of creation can involve transformation and/or conversion. Transformation involves rearrangement to create new manifestations, effects, or outcomes. For example, the assembly of component parts to produce a new product. Conversion involves changing the essence of something from one expression to another. For example, ideas into machines, machines into products, products into money. Money obtained from the sales of products is a method of counting wealth. It is not in itself wealth.

\section{Collaboration vs cooperation}

People cooperate routinely with self-interest and economic gain in mind. This is the basis of extant economic literature and current thinking. It is also the claim of morality in objectivism (Rand, 1961, 1990). It is also justified by Adam Smith's $(1776,2010)$ invisible hand characterization of the positive unintended consequences of the individual pursuit of one's own wants and needs. The butcher, the baker, and the brewer provide goods and services to each other out of self-interest and the unplanned result of this division of labor is a better standard of living for all three. But this is cooperation, not collaboration (see Figure 1). The mainstream of the field of economics gives explicit consideration to cooperation but much less to collaboration. In mainstream economics, Hayek (1945, 1994) depicts a market economy as a mechanism of cooperation that allows people to take advantage of the knowledge others have without having to acquire the knowledge themselves. In political philosophy and distributive justice, Rawls (1971) 

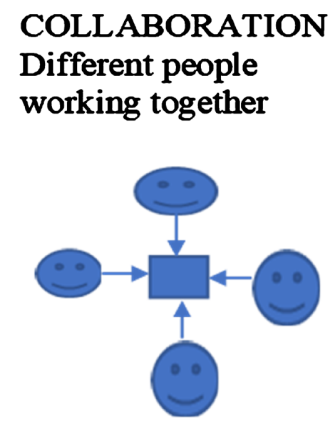

Towards our shared goal

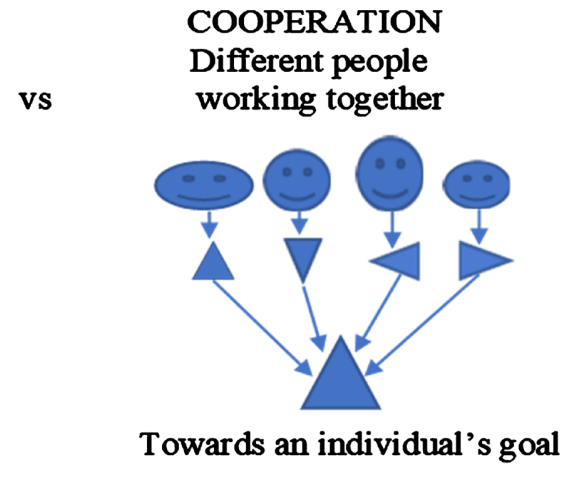

COOPERATION

Different people

working togethe

Towards an individual's goal

Figure 1. Collaboration vs cooperation. Source: own schematic.

uses the term cooperation to expound on a concept of social justice. It is not unusual for cooperation and collaboration to be confused. As a result, the extant literature refers to all community economic development as collaboration when in fact it is cooperation wherein participating entities are working together with their self-interest in mind, not collaboration. When correctly defined, the economic literature on collaboration shrinks. For example, Lowitt (2013) explicitly describes an economy in which "private, public, and civil sectors work together for their own good and for the collective." But this is not collaboration because the parties are working for "their own good." Our research pertains strictly to mainstream economic collaboration. This is not a mere semantic distinction. Collaboration is operationally different from cooperation and produces quite different outcomes. Collaboration creates things that were not previously in existence. This paper contributes what might be considered the study of the advancement from economic cooperation to economic collaboration for the purpose of extraordinary development.

Before the work of psychologist (Tomasello, 2001; Tomasello et al., 2012), cognitive scientists studied human aggression to explain human interactive behavior. Economists studied cooperation and self-interest. As an alternative, in his study of ontogeny, Tomasello observed that while cooperation can result in the unintended consequences of mutual benefit, collaboration is planned intentionally by participants to provide for their mutual benefit. Collaboration includes cooperation but goes beyond cooperation in so far as it exceeds its capability for human advancement and economic development. Intentional mutual consequences are measured relative to shared goals. An example of collaboration that is of particular interest here is the fundamental elements of capitalism, democracy, and rule of law acting in pursuit of extraordinary economic growth. Together with natural resources and geography, these explain 90\% of GDPppp, and human capital constitutes $85 \%$ of total capital (Ridley, 2020a, 2020b). Various species in the animal kingdom demonstrate cooperation. Human beings are not only intelligent they comprise a social species capable of extensive cooperation. Moreover, they collaborate. They are capable of formulating and pursuing shared intentionality, values and goals. Only human beings demonstrate colla- 
boration. "It is not the strongest of the species that survive, nor the most intelligent, but the one most responsive to change" (Darwin, 1809-1882). Ridley (2020a, 2020b) refers to entrepreneurship as an act of giving. In order for one to recognize that it is collaboration as opposed to intelligence that is responsible for the extraordinary engineering achievements of mankind, one only has to imagine millions of the most super-intelligent people working not together but separately. How will that work out for them?

Division of labor, production and trade will provide for the efficient deployment of endogenous capital stock, and ordinary economic growth ("many hands make light work," John Heywood (1497-1580)). We measure this by improvement in GDP. But Ridley $(2018$, 2020a) shows that $21 \%$ of GDP is required for reinvestment in growth and to cover maintenance, depreciation and obsolescence. Without reinvestment, GDP will decline and its contribution to wealth will decline monotonically to zero. Exogenous human capital ideas of imagination and creativity are required for the creation of new products and services for new economic growth ("teamwork makes the dream work" (Maxwell, 2002)). This process requires collaboration. At the time of this collaboration, there is no clearly identifiable product to trade and therefore no measurable self-interest. There has to exist a human propensity to collaborate for planned intentional mutual benefit. Inventors can only envisage applications, utility and benefit of their technology to their community. We attribute their collaboration to that which is borne out of altruism.

\section{Development}

In this paper, we consider the division of reinvestment into two parts, namely private reinvestment and public reinvestment. We are interested in the public sector reinvestments in infrastructure, education, health care and welfare transfer payments. The purpose of this paper is to explore the way in which collaboration can apply a part of reinvestment obtained from taxation to the development of the economy for the benefit of people and society, and the advancement of future economic growth. Entrepreneurship (see also Schumpeter (1911, 1928, 1954) who initiated the theory of economic growth based on entrepreneurship) via collaboration, has demonstrated the creation of massive wealth in some countries (Ridley, 2020a, 2020b; de Silva, Ridley, \& Green, 2020; Ngnepieba et al., 2018). One would think that such massive wealth could provide an adequate living standard for all members of society. Economic growth is necessary but not sufficient for economic development. Per capita GDP is an average, but it is not necessarily uniformly distributed. A high GDP may be Pareto (1906, 1848-1923) distributed such that there are a few rich people and many poor people. The rich might very well be deserving of the money that they earn and praise for the jobs they create, and the poor may not be entitled to the money earned by the rich. So, to improve the possibility of a large middle class, government reinvestments in the development of infrastructure: roads, air and seaports, housing, healthcare, education, water, gas, electricity, sanitation, democracy, rule of law, anti- 
trust protection, anti-discrimination, the common defense, etc., are required to improve the wellbeing of members of society while increasing their personal value that can be converted to even more wealth.

Much of the infrastructure required for social wellbeing is also required by the private sector. For example, roads transport goods directly or indirectly from factories to commercial distribution outlets. Roads also transport customers to distribution outlets. Therefore, the users of roads are symbiotic. Likewise, so are health, water, and education, etc. Still, no one entity is willing to provide these infrastructures for the free usage of all entities. Therefore, they must be accomplished collectively by means of government and government funding must be obtained from taxes. Hence there are shared goals, objectives, and rewards, making development a collaborative enterprise.

\section{Research question}

We know that collaboration converts capital into extraordinary economic growth. The research question then is: does collaboration result in the conversion of economic growth into extraordinary economic development and how does this occur in practice? This paper illustrates how collaboration leads to extraordinary economic development.

\section{Organization}

The remainder of the paper is organized as follows. Section 2 is a review of related literature on the economics of cooperation and the psychology of collaboration. Section 3 is a discussion on related development. Section 4 summarizes conclusions and suggestions for future research.

\section{Related Literature}

\subsection{Psychology}

One crucial way in which human beings are unique is their brain size (Gavrilets, 2015; Alexander, 1990; Striedter, 2005; Geary, 2010; Roth \& Dicke, 2005; Flinn, Geary, \& Ward, 2005; Whiten \& Erdal, 2011). The brain is metabolically expensive as it represents about $2 \%$ of body weight but consumes $20 \%$ of body energy (Shultz, Nelson, \& Dunbar, 2012; Holloway, 1996). A reason why one might question the existence of collaboration is related to what is known as the collective action problem. Given the high energy cost of operating the brain, why would a human being that is a member of a group wish to collaborate for the benefit of others? Why not simply let someone else make the effort, save energy and receive the related rewards? (Olson, 1965; Ostrom, 1990; Batina \& Ihori, 2005). Of course, should too many members of the group relinquish their implied responsibilities, the group may become genetically dimorphic. Very few serving the public good and many free riders, the group will likely perish when and wheresoever it is exposed to the vagaries of nature, predators and competing groups. This collective action problem is particularly challenging for animals and human beings (Nunn, 2000; Kitchen \& Beehner, 2007; Willems, Hellriegel, \& Schaik, 2013). Nevertheless, it turns out that the human being, in particular, 
has managed to overcome the problem. The human being has evolved to develop a capacity for collaboration that is exemplary. This has been demonstrated by experiments with small children (Tomasello et al., 2012).

\subsection{Economics}

The mainstream economics literature is replete with research on cooperation but not collaboration. The term cooperation invokes ideas such as game theory. But in fact, game theory as proposed by von Neumann and Morgenstern (1947) and Nash $(1950,1951)$ is concerned with strategic interactions among non-cooperating competing rational participants acting in their own self-interest. Not cooperation much less collaboration. Cooperation, collaboration and coordination are often used interchangeably. We are interested in collaboration where shared goals apply. For example, Chopra and Meindl (2001) refer to coordination in supply chain management without which the supply chain profit cannot be maximized. And it is only when the supply chain profit is maximized that the profits of the member companies of the supply chain will be maximized. Since the member companies must work towards a shared goal, coordination in the chain is an example of what we define as collaboration. An exceptional example of a successful collaboration is Wikipedia (https://www.wikipedia.org/), wherein the participants are unknown to each other. McCartney (2018) explains how collaboration between the Beetles produced a plethora of musical compositions, remarkably, none of which is the same as another. Kondo, Li and Papanikolaou (2020) propose a macroeconomic model in which variation in the level of trust leads to higher innovation, investment, and productivity growth. Growth is a prerequisite for development and more recent research provides evidence of a causal link between trust and economic development (Tabellini, 2010). The Organization for Economic Cooperation and Development (OECD, 2011) elaborates on mechanisms for collaboration. The three dominant theoretical paradigms used to explain European security cooperation-constructivism, institutionalism and liberalism-each yield distinct predictions in this regard (Devore \& Stai, 2019). Consequently, when firms calculate that they would be better served by a national project they will lobby governments to withdraw from collaborative ones. In a similar analysis, Tucker (1991) claims that discrepancies in corporations' size and capabilities facilitates collaboration. Firms of an analogous size and with similar core competencies will, within this context, fail to collaborate because of their preoccupation with relative gains, while those that differ will face fewer obstacles. It is thus complementary, rather than competitive, corporations that will collaborate most effectively. Ljungholm (2014) examines the process by which citizens and stakeholders collaborate to make, carry out, and enforce public policy.

\section{Economic Development through Collaboration}

Economic development is the process by which the overall health, well-being, 
and academic level of the general population improve. Both economic and social conditions are considered. GDP is the value of all the products and services that an economy produces. The human being is naturally impecunious therefore wealth must be created. Social development over and above GDP is desirable but there will be no development and no wealth for anybody if there is no GDP. Still, what does it pay us to attain economic growth just for the sake of growth? Growth for the sake of growth is not unlike intranational mercantilism. What if growth occurs in the midst of persistent poverty? What if the unemployed were once employed in an industry where their efforts led to automation and their replacement by machines, at least until they acquire more education and skills? What if unemployment results in haves and have nots, speculation on conspiracies (whether justifiable or not), social unrest and rioting? Our focus on collaboration then, is on its role in reinvestment in the wellbeing of society as a whole. A solution for ending unemployment is discussed later at the end of this section.

\subsection{Innovation as a Proxy for Collaboration}

We posit that collaboration is necessary for extraordinary economic development. We assume that GDP that can support development already exists. There are no published data for collaboration by country. But collaboration is often used synonymously with innovation (Hastings \& Meyer, 2020). And we know from the findings by Ridley and Koroviakovskya (2021) that GDP is correlated with the world intellectual property organization (WIPO) global innovation index (GII) (Indicator Rankings \& Analysis | Global Innovation Index). Therefore, we know that growth is correlated with collaboration. The question that remains is what is the relationship between collaboration and development?

A component of human capital is the capital stock of knowledge. Knowledge is acquired through education. Ridley, Ngnepeiba and de Silva (2021) showed that the indicator of successful learning is the normal distribution of test scores obtained by active learning teaching methodology. They suggest that the key element of active learning responsible for success is collaboration (see also Volpe, 1984). It seems reasonable to think that education has consequences for economic development. So, this is our preliminary indicator that collaboration is a causal factor in both education and development. The distribution of capital (including that required from learning) is Pareto (1906, 1848-1923) (similar to lognormally) distributed (Ridley \& Koroviakovskya, 2021). The Pareto distribution implies that $80 \%$ of capital is possessed by $20 \%$ of the human population. If development is dependent on capital, it is unreasonable to expect that the development of people will be naturally uniformly distributed. Therefore, what we mean by collaboration between people, including the rich and the poor, is a collaboration designed to improve infrastructure that will make it possible for the least amongst us to obtain a living wage or better. Also, to experience an improved living standard by virtue of technology enhancement, labor-saving devices, life expectancy, infant mortality, food, clean drinking water, sanitation, and reasonable leisure time. 


\subsection{Human Development}

The published measure that is designed to reflect development is the human development index (HDI)

(https://www.investopedia.com/terms/h/human-development-index-hdi.asp).

The HDI is a statistic developed and compiled by the United Nations to measure various countries' levels of social and economic development. It focuses on human physical and educational wellbeing. Its purpose is to show that even if a country has a high economic income, that country has to adopt policies which use that income for the benefit of its citizens. HDI is a geometric mean of three categories of human achievement: life expectancy using a minimum of 20 years and a maximum of 85 years, two components of education (a: average years of education for adults over 25; b: average years of expected education for children entering school), gross national income per capita with a range of $\$ 100$ to a maximum of $\$ 75,000$. It does not account for inequality, poverty, human security and safety, and empowerment. Nor does it account for infrastructure. Still, it is the best-published indicator available on development.

The set of HDI and GII for 79 countries for which data are available is given in Table 1. They represent almost all people in the world. The remaining countries have populations of less than one million and/or do not provide all data.

\subsection{Distribution}

Our investigation begins with an analysis of the distribution of HDI and the extent of current achievement in development. A histogram of HDI is given in Figure 2. The shape has the appearance of a positive exponential distribution. About one-third (26 countries) have achieved a high level of HDI (0.878 - 0.957). About one-half (35 countries) have achieved moderate HDI $(0.72-0.878)$. About one-fifth (18 countries) have not achieved a functional level of HDI (below 0.72). We speculate that low levels of HDI are due to a lack of collaboration, ceteris paribus. High HDI cannot be achieved without collaboration. Collaboration is a worthwhile, easily available, accessible feature of humanity that many countries have not availed themselves of.

\subsection{HDI vs GII}

Next, we consider the impact of GII. A graph of HDI versus GII is plotted in Figure 3. From the graph, we see that HDI is highly positively correlated with GII. As innovation increases, so does human development. The GII values are relative in rank but have no meaning as an absolute measure. Similarly, the HDI values are a composite of variables measured in units of time and dollars and have no meaning as an absolute measure. There are no GII values below 20. If innovation could theoretically go to zero, human development would be very low and wealth that is subject to depreciation and obsolescence would decline. The linear correlation coefficient is 0.84 . 
Table 1. Human development index (HDI) by country (2019), Global innovation index (GII), Natural resources (N), Latitude (L).

\begin{tabular}{|c|c|c|c|c|c|c|c|c|c|}
\hline Country & $\begin{array}{c}\text { Human } \\
\text { development } \\
\text { index } \\
\text { (HDI) }\end{array}$ & $\begin{array}{c}\text { Global } \\
\text { Innovation } \\
\text { Index (GII) }\end{array}$ & $\begin{array}{c}\text { Natural } \\
\text { Resources } \\
\text { Rents \$ (N) }\end{array}$ & $\begin{array}{l}\text { Latitude } \\
\text { (L) }\end{array}$ & Country & $\begin{array}{l}\text { Human } \\
\text { developm } \\
\text { ent index } \\
\text { (HDI) }\end{array}$ & $\begin{array}{c}\text { Global } \\
\text { Innovation } \\
\text { Index (GII) }\end{array}$ & $\begin{array}{c}\text { Natural } \\
\text { Resources } \\
\text { Rents \$ (N) }\end{array}$ & $\begin{array}{c}\text { Latitude } \\
\text { (L) }\end{array}$ \\
\hline Argentina & 0.845 & 30.65 & 847.476 & 0.3778 & Latvia & 0.866 & 43.18 & 642.411 & 0.6333 \\
\hline Armenia & 0.776 & 32.81 & 318.396 & 0.4444 & Lebanon & 0.744 & 28.22 & 0 & 0.3722 \\
\hline Australia & 0.944 & 51.98 & 3584.35 & 0.3 & Lithuania & 0.882 & 41.19 & 272.59 & 0.6222 \\
\hline Austria & 0.922 & 51.32 & 186.56 & 0.5244 & Macedonia & 0.774 & 29.91 & 495.726 & 0.4611 \\
\hline Bangladesh & 0.632 & 23.06 & 115.294 & 0.2667 & Malawi & 0.483 & 23.09 & 155.68 & 0.1478 \\
\hline Belgium & 0.931 & 50.5 & 43.139 & 0.5661 & Malaysia & 0.810 & 43.16 & 2514.5 & 0.0256 \\
\hline Bolivia & 0.718 & 22.88 & 1002.064 & 0.1889 & Mauritius & 0.804 & 31.31 & 0 & 0.2241 \\
\hline Botswana & 0.735 & 28.16 & 545.6 & 0.2444 & Mexico & 0.779 & 35.34 & 1382.15 & 0.2556 \\
\hline Brazil & 0.765 & 33.44 & 985.455 & 0.1111 & Mongolia & 0.737 & 35.9 & 3945.189 & 0.511 \\
\hline Bulgaria & 0.816 & 42.65 & 358.52 & 0.4778 & Morocco & 0.686 & 31.09 & 289.081 & 0.3556 \\
\hline Canada & 0.929 & 52.98 & 2338.284 & 0.6667 & Namibia & 0.646 & 28.03 & 202.464 & 0.2444 \\
\hline Chile & 0.851 & 37.79 & 3712.177 & 0.3333 & Netherlands & 0.944 & 63.32 & 479.6 & 0.5811 \\
\hline China & 0.761 & 53.06 & 740.544 & 0.3889 & Nigeria & 0.539 & 22.37 & 944.424 & 0.1111 \\
\hline Colombia & 0.767 & 33.78 & 1388.44 & 0.0444 & Norway & 0.957 & 52.63 & 7186.762 & 0.6889 \\
\hline $\begin{array}{c}\text { Cote } \\
\text { d'Ivoire }\end{array}$ & 0.538 & 19.96 & 260.484 & 0.0889 & Oman & 0.813 & 32.8 & $17,012.636$ & 0.2333 \\
\hline Croatia & 0.851 & 40.73 & 356.099 & 0.5011 & Panama & 0.815 & 32.37 & 97.73 & 0.1 \\
\hline Denmark & 0.940 & 58.39 & 758.625 & 0.6222 & Peru & 0.777 & 31.8 & 1150.42 & 0.1111 \\
\hline $\begin{array}{c}\text { Dominican } \\
\text { Republic }\end{array}$ & 0.756 & 29.33 & 70.07 & 0.2111 & Philippines & 0.718 & 31.56 & 223.168 & 0.1444 \\
\hline Egypt & 0.707 & 27.16 & 1190.062 & 0.3 & Poland & 0.880 & 41.67 & 454.446 & 0.5778 \\
\hline El Salvador & 0.673 & 25.11 & 137.02 & 0.15 & Portugal & 0.864 & 45.71 & 135.345 & 0.4367 \\
\hline Estonia & 0.892 & 50.51 & 780.64 & 0.6556 & Romania & 0.828 & 37.59 & 434.368 & 0.5111 \\
\hline Finland & 0.938 & 59.63 & 528.593 & 0.7111 & Russia & 0.824 & 37.9 & 4596.412 & 0.6667 \\
\hline France & 0.901 & 54.36 & 40.538 & 0.5111 & Saudi Arabia & 0.854 & 34.27 & $24,272.304$ & 0.2778 \\
\hline Germany & 0.947 & 58.03 & 92.432 & 0.5667 & Serbia & 0.806 & 35.46 & 441.474 & 0.49 \\
\hline Ghana & 0.611 & 24.52 & 728.112 & 0.0889 & Singapore & 0.938 & 59.83 & 0 & 0.0136 \\
\hline Greece & 0.888 & 38.93 & 51.908 & 0.4333 & Slovakia & 0.860 & 42.88 & 141.395 & 0.5378 \\
\hline Hungary & 0.854 & 44.94 & 150.114 & 0.5222 & Slovenia & 0.917 & 46.87 & 89.601 & 0.5111 \\
\hline India & 0.645 & 35.18 & 342.672 & 0.2222 & South Africa & 0.709 & 35.13 & 1204.648 & 0.3222 \\
\hline Indonesia & 0.718 & 29.8 & 809.476 & 0.0556 & Spain & 0.904 & 48.68 & 33.835 & 0.4444 \\
\hline Iran & 0.783 & 33.44 & 5128.242 & 0.3556 & Sweden & 0.945 & 63.08 & 508.409 & 0.6889 \\
\hline Ireland & 0.955 & 57.19 & 51.284 & 0.5889 & Switzerland & 0.955 & 68.4 & 0 & 0.5222 \\
\hline Israel & 0.919 & 56.79 & 132.544 & 0.3478 & Thailand & 0.777 & 38 & 716.634 & 0.1667 \\
\hline
\end{tabular}




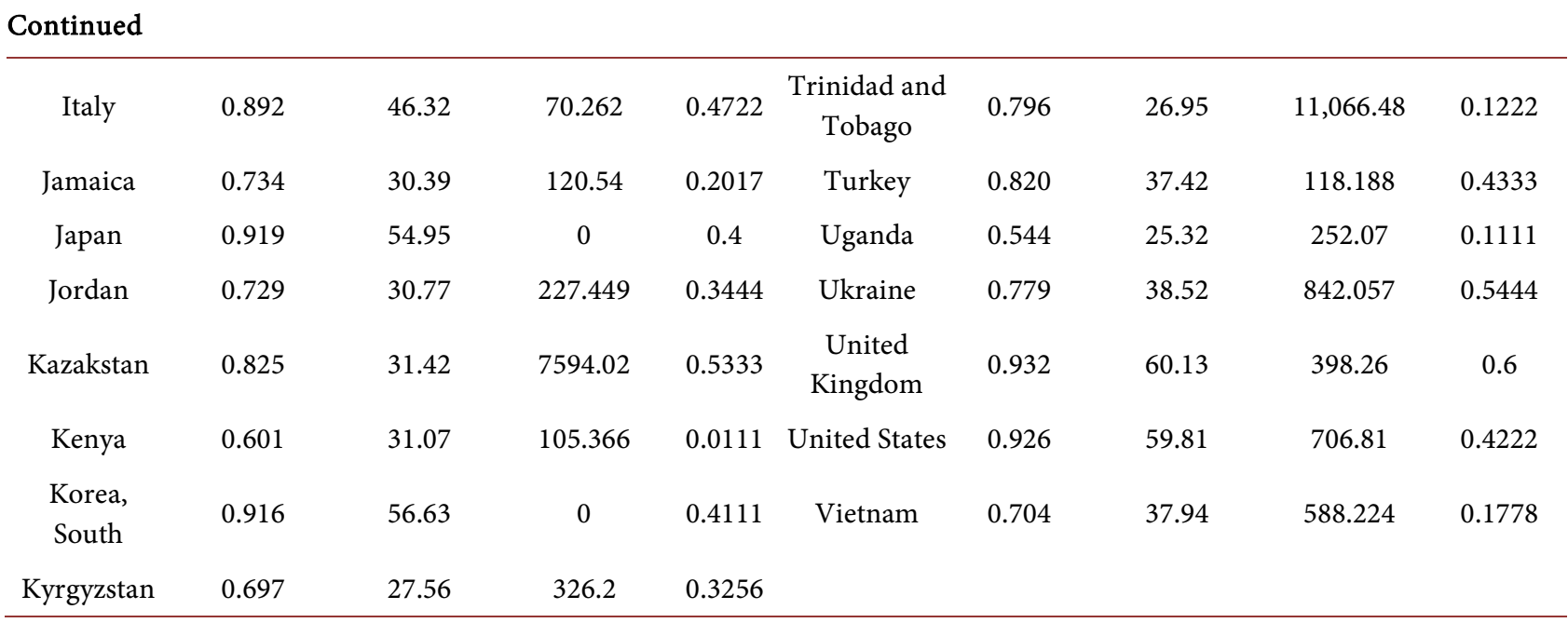

Source: HDI (https://www.investopedia.com/terms/h/human-development-index-hdi.asp);

GII (https://www.globalinnovationindex.org/analysis-indicator); N (http://data.worldbank.org/indicator/NY.GDP.TOTL.RT.ZS).

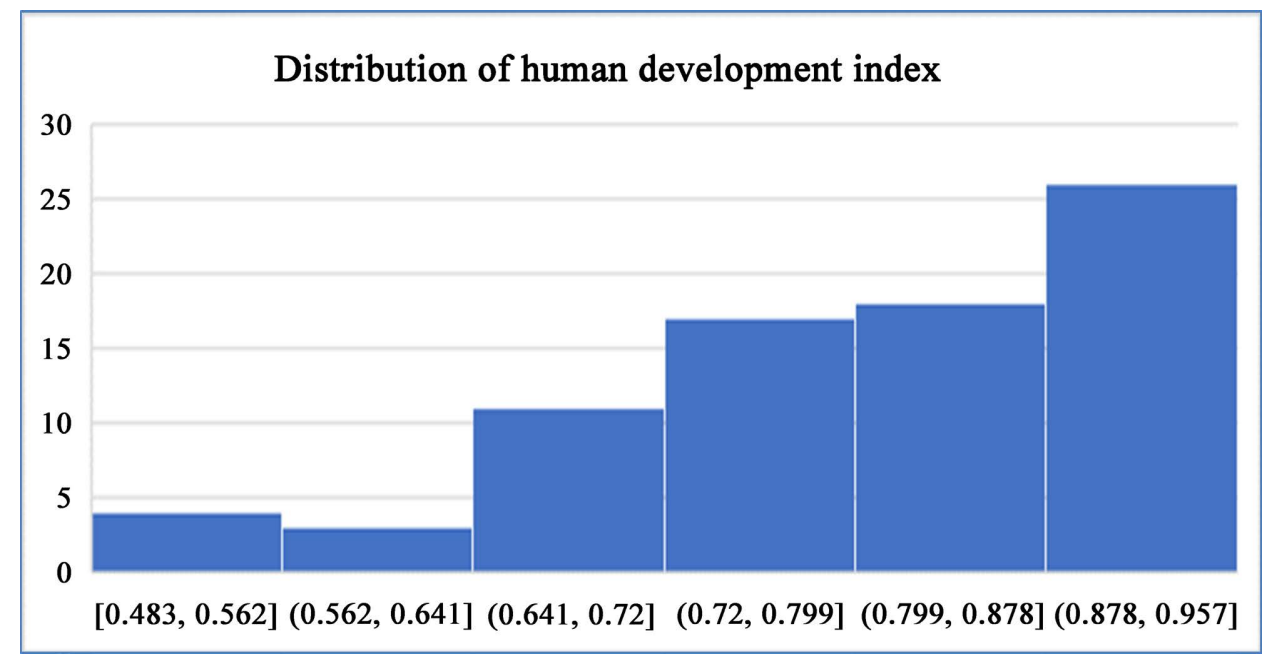

Figure 2. Distribution of human development index (HDI).

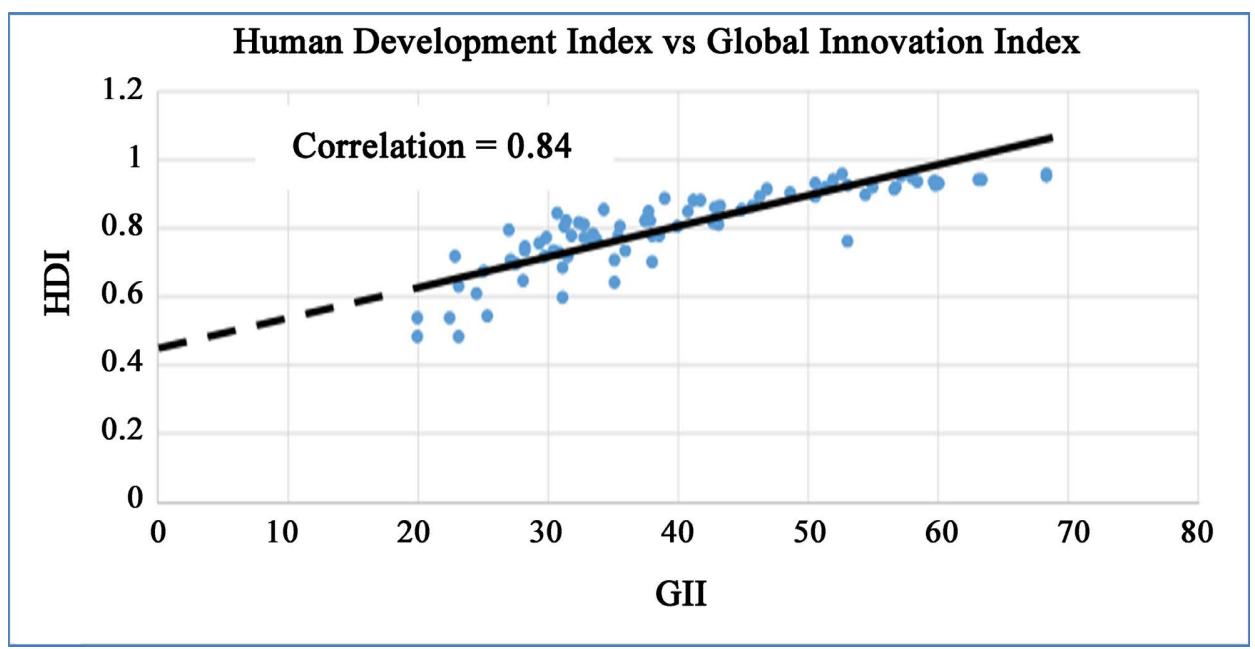

Figure 3. Human development index (HDI) vs Global innovation index (GII). 
Consider the model:

$$
\mathrm{HDI}=\beta_{0}+\beta_{\mathrm{GII}} \mathrm{GII}+\beta_{\mathrm{N}} \mathrm{N}+\beta_{\mathrm{L}} \mathrm{L}+\varepsilon,
$$

where $\beta_{0}$ is the intercept on the HDI axis, $\beta_{\mathrm{GII}}$ is the slope of the trend line, and $\varepsilon \sim \mathbb{N}\left(0, \sigma^{2}\right)$ is a normally distributed random error with a mean of 0 and constant variance $\sigma^{2}$. GII is a reflection of human ideas of imagination and creativity and is, therefore, an exogenous variable, expected to yield unbiased estimates of the regression coefficients. GII is a policy of choice variable. $\mathrm{N}$ represents natural resources and is measured by natural resources rents. $\mathrm{L}$ represents latitude and therefore geography and is measured by the absolute distance from the equator (data available from La Porta et al. 1999). N and L are obviously exogenous. Furthermore, they are not policy variables. It is reasonable to think that $\mathrm{N}$ and $\mathrm{L}$ might be resources for, or otherwise impact economic development. But a country cannot choose its natural resources or geography.

Consider the null hypothesis $\mathrm{H}_{0}$ that $\beta_{\mathrm{GII}}=0$ and there is no significant relationship, versus the alternative $\mathrm{H}_{1}$ that $\beta_{\mathrm{GII}} \neq 0$ and there is a significant relationship between HDI and GII.

$$
\begin{aligned}
& \mathrm{H}_{0}: \beta_{\mathrm{GII}}=0 \\
& \mathrm{H}_{1}: \beta_{\mathrm{GII}} \neq 0
\end{aligned}
$$

The least-squares linear regression fit that corresponds to Figure 3 is

$$
\begin{array}{lcccc}
\text { hdi }=0.4732+0.006825 \mathrm{GII}+0.000005 \mathrm{~N}+0.136843 \mathrm{~L} & \\
t= & (10.5) & (3.26) & (3.43) & \text { adjusted } R^{2}=0.77 . \\
r= & 71 \% & 3 \% & 3 \% &
\end{array}
$$

where hdi is the fitted value. The coefficient of multiple determination adjusted $R^{2}=0.77$. We can test the significance of this relationship as follows. Our regression computation gives us an estimate for $\beta_{\mathrm{GII}}, b_{\mathrm{GII}}=0.006825$ with standard error of estimate $s_{b_{\mathrm{GII}}}=0.000573$. Since $t=b_{\mathrm{GII}} / s_{b_{\mathrm{GII}}}=0.006825 / 0.000650134=10.5>t_{\alpha=0.01, v=79-4}=2.64$, where $v$ is the number of degrees of freedom, we conclude with a level of significance $\alpha=1 \%$ that there is a statistically significant relationship between HDI and GII. The coefficients for $\mathrm{N}$ and $\mathrm{L}$ are evaluated similarly and found to be statistically significant. There is only a $1 \%$ chance that this conclusion is reached erroneously. The partial correlations ( $r$ ) show the contributions from GII, N and L to explaining the variation in hdi. GII contributes $71 \%$. Although $\mathrm{N}$ and L are significant, they contribute only $3 \%$ each and are therefore negligible. We, therefore, attribute human development to collaboration.

A plot of the residuals is shown in Figure 4. It has the appearance of being random. There are no patterns that imply any missing variables. The distribution of the residuals is shown in Figure 5. It has the appearance of being near symmetrical, with some skewness to the left. A normal probability plot is shown in Figure 6. The approximately straight line suggests residuals that are close to normally distributed. The related statistics are: average $=0$, standard deviation $=$ 


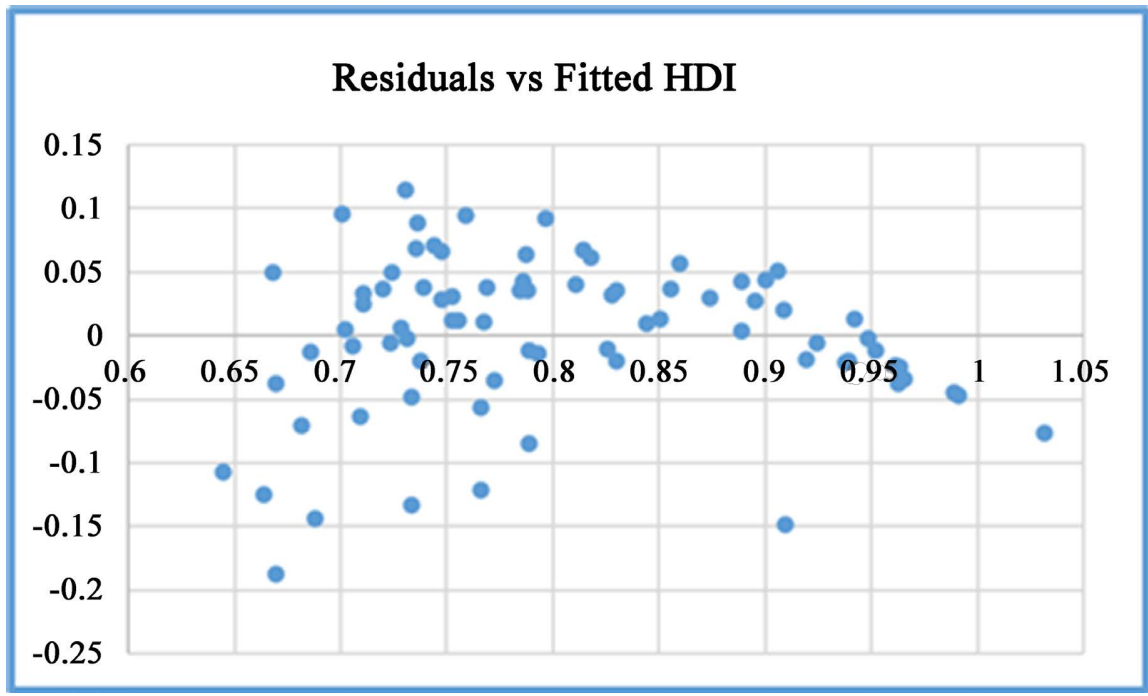

Figure 4. Residuals.

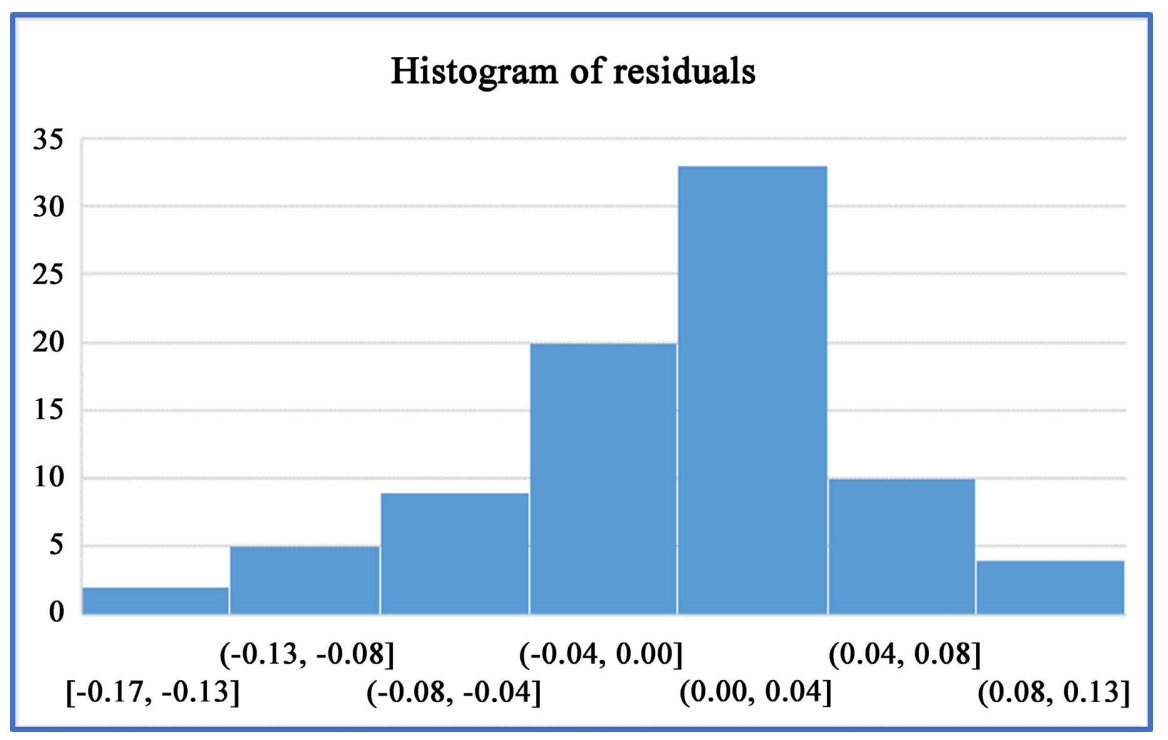

Figure 5. Histogram of residuals.

0.051992, skewness $(S)=-0.6674$, kurtosis $(K)=3.870263$ and the Jarque and Bera $(1980,1987)$ test statistic JB $=$ $(n / 6)\left(S^{2}+(1 / 4)(K-3)^{2}\right)=(79 / 6)\left((-0.6674)^{2}+(1 / 4)(3.870263-3)^{2}\right)=8.36 \quad$. The theoretical JB statistic follows a Chi-square distribution. With a 0.01 level of significance and 2 degrees of freedom, Chi-square $=9.21$. Since $\mathrm{JB}=8.36<9.21$, at the specified level of significance, we accept that the residuals are normally distributed.

\subsection{Causation}

The small size of $b_{\mathrm{GII}}=0.006825$ might create an impression that the effect of GII on hdi is small. But this slope coefficient would be large if the scale value were made smaller. The important thing is the large $t$ ratio. The regression analysis tells us that HDI and GII are highly correlated, but it does not imply causation. 


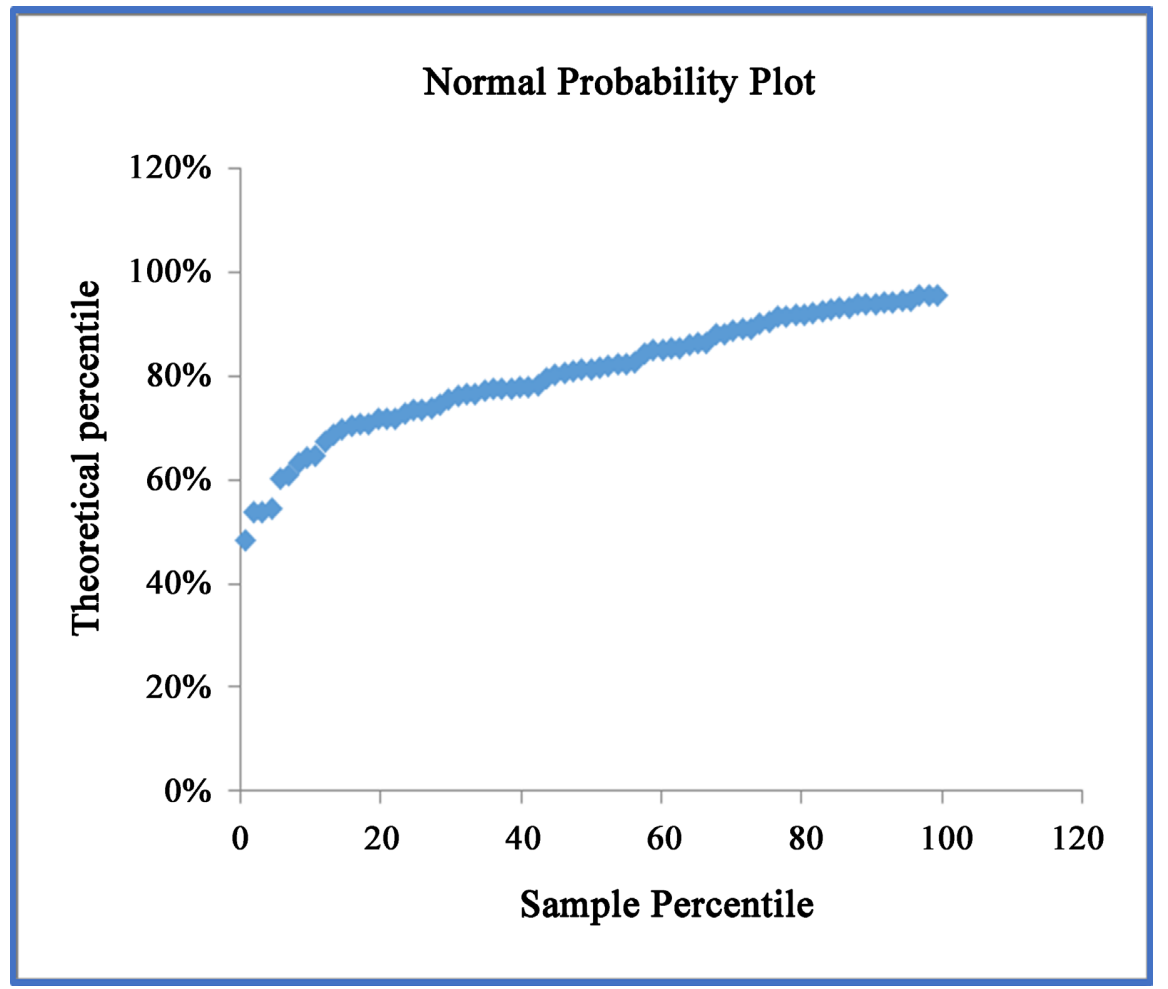

Figure 6. Normal probability plot.

Also, GII is exogenous so it cannot be caused by HDI. Therefore, if in fact there is causation, it must be that GII causes HDI. What the significance of the statistical fit, and the closeness of the data points to the line in Figure 3 tells us is that the way that collaboration (proxied by GII) converts economic growth into economic development is close to being the same everywhere in the world. That is, there is no significant difference from country to country. However, some countries exhibit a high level of collaboration and experience a high level of development, ceteris paribus. On the other hand, some countries exhibit a low level of collaboration and experience a low level of economic development. Therefore, as a policy choice it is better to collaborate, and to do so maximally. It is pointless to opine about the absence of natural resources and geography.

Remark 1 . The low (3\%) contribution of natural resources may be surprising. However, if one thinks about it, many high natural course countries are poor (Russia, Nigeria, Brazil, etc.) and low natural resource countries are rich (Japan, South Korea, Singapore, Bermuda, Cayman Islands, etc.). There is also the natural resource curse that in the absence of collaboration can induce currency mismanagement, loss of traditional craft and agricultural exports, unemployment, corruption, and social chaos (Auty, 1993; Humphreys, 2005; Norman, 2009; Sachs \& Warner, 2001; Ross, 2001; Sachs \& Warner, 2001; Wadho, 2014). What might otherwise be a geographical inequality due to latitude is easily overcome simply by collaborating in trade to even the playing field.

Remark 2. Knowledge (and education) are derived from human development 
and is therefore correlated with HDI. But collaboration is an act of choice and will. Collaboration is an exogenous causal factor that contributes to endogenous education. Collaboration and creativity are distinctly different from knowledge. No amount of knowledge implies creative ability.

Remark 3. The possibility of capital contributing to HDI was a consideration. Total market capitalization was the variable used. When it was added to the regression model, its coefficient was not statistically significant. Therefore, it was omitted from the final model.

\subsection{Collaboration vs Genetic Variance}

One of the best examples that illustrate the impact of collaboration on economic development is the contrast between North and South Korea. These are emblematic of disparate economies that once were formerly one country of common geography, ethnicity and culture. Now, they are separated only by differences in their policies on collaboration, economic development and the $38^{\text {th }}$ parallel. Various reasons have been suggested for why some countries are more developed than others. For example, according to Galor and Ashraf (2013), economic development is determined by the characteristic of genetic diversity. They suggest that low development is associated with high genetic diversity in Africa and low genetic diversity in native America. Furthermore, they suggest that Asian, European and Euro-American settlers comprise medium genetic diversity associated with high development. But their argument does not account for the very large differences in development between countries that have the same genetic diversity. For example, between Western and Eastern Europe, between Japan and China and between North Korea and South Korea (see Acemoglu, Johnson and Robinson (2005) for an account of a natural experiment represented in the two Koreas divide only by the $38^{\text {th }}$ parallel and their institutions, no other variables). Institutional effects from learning and developing human capital can outweigh genetic effects (Faria et al., 2016). Even if it were true that genetic inheritance includes human capital that is passed on through knowledge and skills by nature and nurture, then such capital is transportable between countries. All capital, including human capital will travel from undemocratic law unabiding countries to democratic lawabiding countries where collaboration is practiced. There, it will be applied to promote development. In any case, even if a country is immutably stuck with less than maximal talent, it should still focus on raising its level of collaboration to maximize its own economic development.

Some former low collaboration low development countries have transformed themselves into high collaboration high development countries in just a few decades. For example, Poland, Chile, Hong Kong, Singapore, and South Korea made the transition in a remarkably short time. Many other countries have ignored the importance of collaboration and have remained poor. So much so that only 10 percent of the people in the world are now rich and getting richer, while 90 percent live on about 2 - 3 dollars. 


\subsection{Collaboration in Decision Making}

Many decisions that relate to development projects require a democratic process as an element of collaboration. Ridley and de Silva (2019) show how corrupt dictatorship is an obstacle to economic growth. Such a democratic process may require voting on projects to be chosen. From Arrow's (1963) impossibility theorem, we know that the individual project ranking cannot equate to the population rankings while simultaneously satisfying non-dictatorship, Pareto efficiency, individual sovereignty, unanimity, freedom and independence from irrelevant alternatives, and uniqueness of group rank. That is, if all of the latter four are satisfied, then a dictatorship must apply. To overcome this problem, a governmental body can make the project decision in place of a plebiscite. They can represent and act on behalf of the general population. Examples of governing bodies are federal, state, county, city governments, economic development councils, utilities, port authorities, and school boards, etc. The governing body can be elected for a limited fixed period of time, in accordance with a written constitution, and can serve as a temporary dictatorship. It may assuage one's fears to recognize that although the impossibility theorem could also apply to the governing body, the impact is mitigated since there are a small number of representative legislators who therefore can bargain with each other to reach agreements. See also Tideman and Tullock (1876), and Clarke (1971) on the process of making choice. In passing, we note that if the Ridley (2017) micro intrapreneurship proposal is adopted, the whole Arrow question of how to construct a collective decision-making mechanism that can maximize social welfare is avoided. This is just as well since there is no such thing as social welfare. Welfare is a concept that applies only to individuals.

An influence diagram in Figure 7 depicts the factors influencing economic

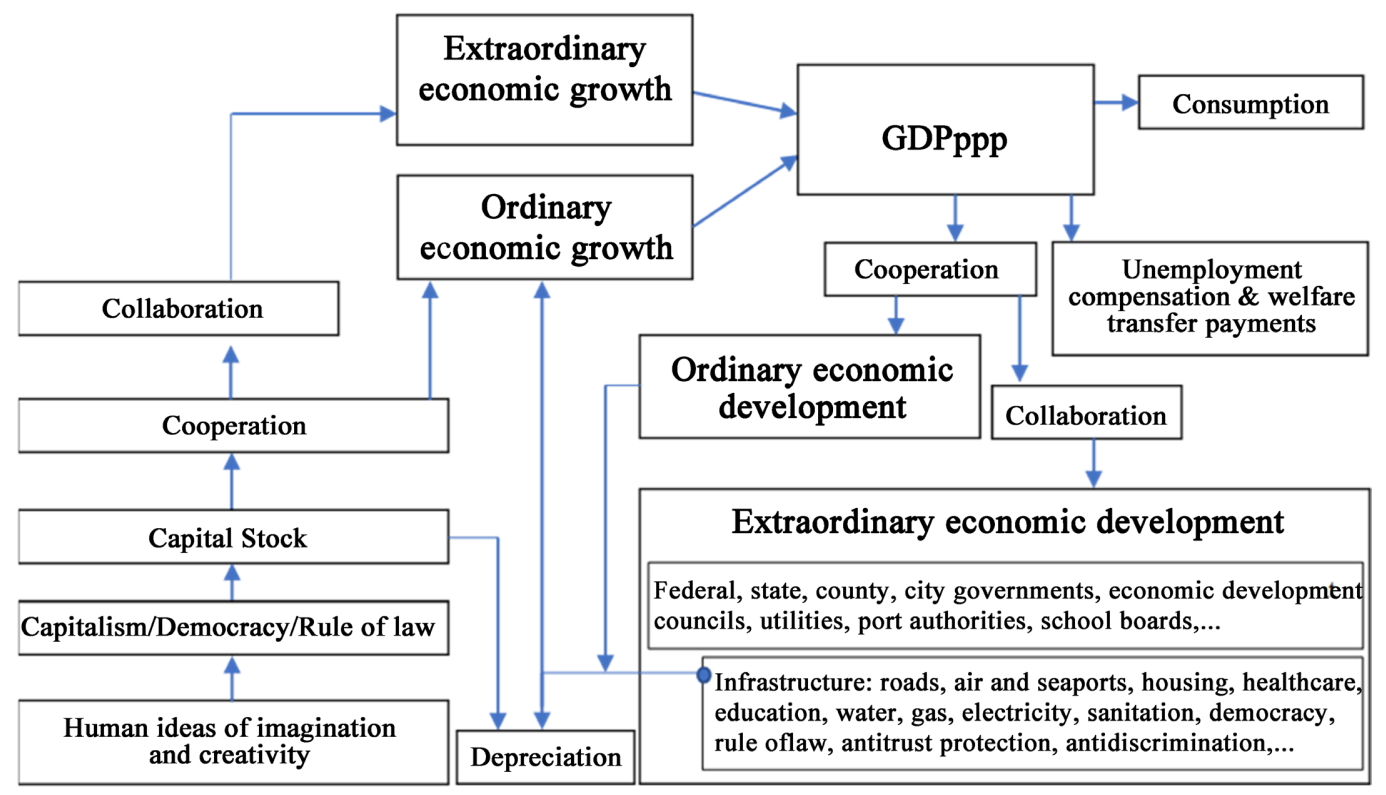

Figure 7. Economic development influence diagram. Source: own schematic. 
growth and development. We know from Ridley (2020a, 2020b) that cooperation is required for ordinary economic growth. The left side of the schematic represents private sector activities. They begin with human capital ideas of imagination and creativity. In the presence of capitalism, democracy and rule of law, human capital is converted into capital stock of knowledge, machines, computers, recordings, etc. Capital stock is subject to depreciation. We also know from Ridley and Koroviakovskya (2021) that collaboration is required for extraordinary economic growth. Both of these result in GDPppp. The GDPppp is commonly referred to as standard of living. But as mentioned above, GDPppp may be very poorly distributed. Furthermore, it is not by itself economic development.

After consumption, the remaining wealth must be intentionally converted to economic development. The lower right side of the schematic diagram represents public sector activities. Cooperation is required for ordinary economic development and collaboration is required for extraordinary economic development. Both the private sector and the public sector utilize the infrastructure developed, subject to depreciation, to continue future economic growth. The public sector development activities depicted in Figure 7 are typically macro-economic in design. But some activities will need to be micro-economic. For example, the nonphysical activities of unemployment compensation and welfare transfer payments. While these have the appearance of being macro-economic, contrary to commonly held beliefs, welfare is a concept that applies only to individuals. Therefore, these are questions for microeconomics.

An alternative micro-economic proposal by Friedman (2002) and Friedman and Friedman (1980) was referred to as a negative income tax. Another proposal is universal basic income. Yet another is the symbiotic micro-economic development collaboration between a government and a private business employer referred to as micro intrapreneurship (Ridley, 2017). We recognize that the only source of GDPppp growth is human capital ideas of imagination and creativity (Ridley, 2020a, 2020b). And the source of funding for economic development is GDPppp. Therefore, it behooves us to maintain where possible an educated and healthy population in society. The Ridley (2017) micro intrapreneurship proposal is one wherein the government subsidizes the wages of the inexperienced job seeker. The idea is to provide everybody at least a living wage. The amount of the subsidy is the difference between what an employer values him and is willing to pay, and the living wage. To receive the subsidy, the recipient must work. Work experience is a way for him to acquire the skills needed to close the gap. This might occur in just a few months. When the worker becomes revalued up to the living wage, the government subsidy ends, he can then join the pool of employees who might discover some potential improvements to the operations. His closeness to a particular low-level job activity might allow him to see options that the engineer in a far-removed office would not see. These can then be brought to the attention of the engineer for consideration. That will also benefit 
the economy as it contributes to economic growth. This is a better alternative to welfare transfer payments, the negative income tax, and universal basic income, wherein the recipient is unemployed and therefore represents dead capital.

\section{Conclusion}

Ridley and Koroviakovskya (2021) suggest that while cooperation is responsible for ordinary economic growth, collaboration is responsible for extraordinary economic growth, engineering, and technological achievements. Ridley, Ngnepieba and de Silva (2021) show that learning that takes place in a collaborative mode produces superior outcomes. Superior collaborative learning and outcomes, and subsequent collaborations might also serve in infrastructure and workforce development, and future economic growth.

Economic growth is the source of financing economic development. But it does not happen automatically. Deliberate actions are required to construct infrastructure that we recognize as evidence of development. Ridley (2020a, 2020b) shows that government spending, country size, location, culture and population physical characteristics have a negligible effect on GDPppp. However, infrastructure that is required for economic development will not be constructed by any one person or corporation for the benefit of all others. Therefore, government spending is required for collective and collaborative infrastructure development.

We investigate the relationship between collaboration and economic development. There are no published data for collaboration, so innovation is used as a proxy for collaboration. The two are often used interchangeably. The proxy for economic development is the human development index. We show that there is a significant correlation between collaboration and economic development. Collaboration is obviously exogenous and cannot be caused by economic development. Therefore, if there is a causal relationship between the two, collaboration must be the cause of economic development. About one-fifth of all countries have not attained a functional level of economic development. Collaboration is a feature of humanity that those countries have not availed themselves of. Raising their level of collaboration will facilitate a rise in their level of economic development. Even if certain limiting human or environmental characteristics are obstacles in some nations, collaboration is salutary to economic development in terms of making the best of what is possible. Future research might investigate the causes of why some countries do not collaborate even though it is an easily accessible natural social cognitive competence, and so beneficial to economic development.

\section{Acknowledgements}

The author would like to thank Randall Holcombe for helpful comments and good discussions.

\section{Conflicts of Interest}

The author declares no conflicts of interest regarding the publication of this paper. 


\section{References}

Acemoglu, D., Johnson, S., \& Robinson, J. A. (2005). Institutions as a Fundamental Cause of Long-Run Growth. In P. Aghion, \& S. Durlauf (Eds.), Handbook of Economic Growth (Vol. 1, pp. 385-472). North-Holland. https://doi.org/10.1016/S1574-0684(05)01006-3

Alexander, R. D. (1990). How Did Humans Evolve? Reflections on the Uniquely Unique Species. University of Michigan, Museum of Zoology.

Arrow, K. J. (1963). Social Choice and Individual Values (2nd ed.). Wiley.

Auty, R. (1993). Sustaining Development in Mineral Economies: The Resource Curse Thesis. Routledge.

Batina, R. G., \& Ihori, T. (2005). Public Goods. Theories and Evidence. Solar Phys.

Chopra, S., \& Meindl, P. (2001). Supply Chain Management: Strategy, Planning, and Operations. Prentice Hall.

Clarke, E. H. (1971). Multipart Pricing of Public Goods. Public Choice, 11, 17-33. https://doi.org/10.1007/BF01726210

Darwin, C. (1809-1882). Charles Darwin. Wikipedia.

de Silva, A., Ridley, A. D., \& Green, S. (2020). Entrepreneurial Psychology: Revising the PSYCH 101 Course. Journal of Management and Engineering Integration, 13, 40-52.

Devore, M. R., \& Stai, N. K. (2019). When Collaboration Works: High Politics and Realism's Renaissance in Arms Collaboration Studies. European Review of International Studies, 6, 18-42.

Faria, H. J., Montesinos-Yufa, H. G., Morales, D. R., \& Navarro, C. E. (2016). Unbundling the Roles of Human Capital and Institutions in Economic Development. European Journal of Political Economy, 45, 108-128. https://doi.org/10.1016/j.ejpoleco.2016.08.001

Flinn, M. V., Geary, D. C., \& Ward, C. V. (2005). Ecological Dominance, Social Competition, and Coalitionary Arms Races: Why Humans Evolved Extraordinary Intelligence? Evolution and Human Behavior, 26, 10-46. https://doi.org/10.1016/j.evolhumbehav.2004.08.005

Friedman, M. (2002). Capitalism and Freedom. University of Chicago Press. https://doi.org/10.7208/chicago/9780226264189.001.0001

Friedman, M., \& Friedman, R. (1980). Free to Choose. Houghton, Mifflin, Harcourt Publishing Company, Inc.

Galor, O., \& Ashraf, Q. (2013). The Out of Africa Hypothesis, Human Genetic Diversity and Comparative Economic Development. American Economic Review, 102, 1-46. https://doi.org/10.1257/aer.103.1.1

Gavrilets, S. (2015). Collective Action and the Collaborative Brain. Journal of the Royal Society Interface, 12, Article ID: 20141067. https://doi.org/10.1098/rsif.2014.1067

Geary, D. C. (2010). The Origin of Mind. Evolution of Brain, Cognition, and General Intelligence. American Psychological Association.

Hastings, R., \& Meyer, E. (2020). No Rules \& Rules: Netflix and the Culture of Reinvention. Diversified Publishing.

Hayek, F. A. (1945). The Use of Knowledge in Society. The American Economic Review, $35,519-530$

Hayek, F. A. (1994). The Road to Serfdom (p. 81). The University of Chicago Press.

Heywood, J. (1497-1580). John Heywood. Wikipedia. 
Holloway, R. (1996). Evolution of the Human Brain. In A. Lock, \& C. R. Peters (Eds.), Handbook of Human Symbolic Evolution (pp. 74-125). Clarendom Press.

Humphreys, M. (2005). Natural Resources, Conflict and Conflict Resolution. Journal of Conflict Resolution, 49, 508-537. https://doi.org/10.1177/0022002705277545

Jarque, C. M., \& Bera, A. K. (1980). Efficient Tests for Normality, Homoscedasticity and Serial Independence of Regression Residuals. Economics Letters, 6, 255-259. https://doi.org/10.1016/0165-1765(80)90024-5

Jarque, C. M., \& Bera, A. K. (1987). A Test for Normality of Observations and Regression Residuals. International Statistical Review, 55, 163-172. https://doi.org/10.2307/1403192

Kitchen, D. M., \& Beehner, J. C. (2007). Factors Affecting Individual Participation in Group-Level Aggression among Non-Human Primates. Behaviour, 144, 1551-1581. https://doi.org/10.1163/156853907782512074

Kondo, J., Li, D., \& Papanikolaou, D. (2020). Trust, Collaboration, and Economic Growth. Management Science, 67, 1825-1850.

La Porta, R., Lopez-de-Silanes, F., Shleifer, A., \& Vishny, R. (1999). The Quality of Government. Journal of Law, Economics and Organization, 15, 222-279. https://doi.org/10.1093/jleo/15.1.222

Ljungholm, D. P. (2014). The Process of Collaborative Governing. Geopolitics, History, and International Relations, 6, 105-110.

Lowitt, E. (2013). The Collaborative Economy: How to Meet Business, Social, and Environmental Needs and Gain. John Wiley and Sons, Inc.

Maxwell, J. C. (2002). Teamwork Makes the Dream Work. HarperColins.

McCartney, P. (2018). Paul McCartney Breaks down His Most Iconic Songs. GQ-YouTube.

Nash, J. (1950). Equilibrium Points in n-Person Games. Proceedings of the National Academy of Sciences, 36, 48-49. https://doi.org/10.1073/pnas.36.1.48

Nash, J. (1951). Non-Cooperative Games. The Annals of Mathematics, 54, 286-295. https://doi.org/10.2307/1969529

Ngnepieba, P., Ridley, A. D., Stephens, D., Johnson, L., \& Edington, M. (2018). Entrepreneurial Mathematics: Revising the math101 Course. International Journal of Economics, Business and Management Research, 2, 272-285. https://ijebmr.com/link/287

Norman, C. (2009). Rule of Law and the Resource Curse: Abundance versus Intensity. Environmental Resource Economics, 43, 183-207. https://doi.org/10.1007/s10640-008-9231-y

Nunn, C. (2000). Collective Action, Free-Riding, and Male Extra-Group Conflict. In P. Kappeler (Ed.), Primate Males (pp. 192-204). Cambridge University Press.

OECD (2011). Collaborative Mechanisms for Intellectual Property Management in the Life Sciences. http://www.oecd.org/sti/emerging-tech/48665248.pdf

Olson, M. (1965). Logic of Collective Action: Public Goods and the Theory of Groups. Harvard University Press.

Ostrom, E. (1990). Governing the Commons. The Evolution of Institutions for Collective Action. Cambridge University Press.

Pareto, V. (1906, 1848-1923). Vilfredo Pareto Rule-Bing. https://doi.org/10.1017/CBO9780511807763

Rand, A. (1961). The Virtue of Selfishness. New American Library, Penguin Group. https://www.youtube.com/watch?v=3u8Jjth81_Q 
https://www.youtube.com/watch?v=rydsea_Y8xI

Rand, A. (1990). Introduction to Objectivist Epistemology. Penguin Group.

Randrup, N., Druckemiller, D., \& Briggs, R. O. (2016). Philosophy of Collaboration. In 49th Hawaii International Conference on System Sciences. https://doi.org/10.1109/HICSS.2016.115

Rawls, J. (1971). A Theory of Justice. Harvard University Press.

Ridley, A. D. (2017). Micro Intrapreneurship. International Journal of Social Science \& Economic Research, 2, 4729-4743. http://ijsser.org/uploads/ijsser_02_299.pdf

Ridley, A. D. (2018). General Theory of Economics: CDR Supply Side Scientific Growth Law Unveiled. Theoretical Economics Letters, 8, 3637-3663. https://doi.org/10.4236/tel.2018.815223

Ridley, A. D. (2020a). The Mystery of Wealth: Capitalism. Democracy. Rule of Law. Sciendo (De Gruyter). https://doi.org/10.2478/9788395771361 https://www.amazon.com/s?k=the+mystery+of+wealth+by+ridley\&ref=nb_sb_noss

Ridley, A. D. (2020b). Capitalism Democracy Rule of Law Interactions and Implications for Entrepreneurship and per Capita Real Gross Domestic Product Adjusted for Purchasing Power Parity. Journal of the Knowledge Economy, 12, 384-411. https://doi.org/10.1007/s13132-020-00632-6

Ridley, A. D., \& de Silva, A. (2019). Game Theoretic Choices between Corrupt Dictatorship Exit Emoluments and CDR Benefits: Is There a Nash Equilibrium? The American Economist, 65, 51-77. https://doi.org/10.1177/0569434519878858

Ridley, A. D., \& Koroviakovskya (2021). Economic Growth: The Log Symmetry of Collaborative Learning Populations.

Ridley, A. D., Ngnepieba, P., \& de Silva, A. (2021). The Doctrine of Normal Tendency in Active Learning Teaching Methodology: Investigations into Probability Distributions and Averages. SN Social Sciences, 1, 144. https://doi.org/10.1007/s43545-021-00154-1

Ross, M. (2001). Does Oil Hinder Democracy? World Politics, 53, 326-361. https://doi.org/10.1353/wp.2001.0011

Roth, G., \& Dicke, U. (2005). Evolution of the Brain and Intelligence. Trends in Cognitive Sciences, 9, 250-257. https://doi.org/10.1016/j.tics.2005.03.005

Sachs, J., \& Warner, A. M. (2001). Natural Resources and Economic Development: The Curse of Natural Resources. European Economic Review, 45, 827-838. https://doi.org/10.1016/S0014-2921(01)00125-8

Schumpeter, J. A. (1911). Theory of Economic Development. Harvard University Press.

Schumpeter, J. A. (1928). The Entrepreneur. In M. Becker, T. Knudsen, \& R. Swedberg (Eds.), The Entrepreneur: Classic Texts by J. Schumpeter (pp. 227-260). Stanford University Press.

Schumpeter, J. A. (1954). A History of Economic Analysis. Allen \& Unwin.

Shultz, S., Nelson, E., \& Dunbar, R.I.M. (2012). Hominin Cognitive Evolution: Identifying Patterns and Processes in the Fossil and Archaeological Record. Philosophical Transactions of the Royal Society, 367, 2130-2140. https://doi.org/10.1098/rstb.2012.0115

Smith, A. (1776, 2010). An Inquiry into the Nature and Causes of the Wealth of Nations. Tantor. https://doi.org/10.1093/oseo/instance.00043218

Striedter, G. F. (2005). Principles of Brain Evolution. Sinauer.

Tabellini, G. (2010). Culture and Institutions: Economic Development in the Regions of Europe. Journal of the European Economic Association, 8, 677-716. 
https://doi.org/10.1111/j.1542-4774.2010.tb00537.x

Tideman, T. N., \& Tullock, G. (1976). A New and Superior Process for Making Social Choices. Journal of Political Economy, 84, 1145-1159. https://doi.org/10.1086/260505

Tomasello, M. (2001). The Cultural Origins of Human Cognition. Harvard University Press.

Tomasello, M., Melis, A. P., Tennie, C., Wyman, E., \& Herrmann, E. (2012). Two Key Steps in the Evolution of Human Cooperation. Current Anthropology, 53, 673-692. https://doi.org/10.1086/668207

Tucker, J. (1991). Partners and Rivals: A Model of International Collaboration in Advanced Technology. International Organization, 45, 83-120. https://doi.org/10.1017/S0020818300001405

Volpe, P. E. (1984). The Shame of Science Education. American Zoologist, 24, 433-441. https://doi.org/10.1093/icb/24.2.433

von Neumann, J., \& Morgenstern, O. (1947). The Theory of Games and Economic Behavior. Princeton University Press.

Wadho, W. A. (2014). Education, Rent Seeking and the Curse of Natural Resources. Economics \& Politics, 26, 128-156. https://doi.org/10.1093/icb/24.2.433

Whiten, A., \& Erdal, D. (2011). The Human Socio-Cognitive Niche and Its Evolutionary Origins. Philosophical Transactions of the Royal Society B, 367, 2119-2129. https://doi.org/10.1098/rstb.2012.0114

Willems, E. P., Hellriegel, B., \& van Schaik, C. P. (2013). The Collective Action Problem in Primate Territory Economics. Proceedings of the Royal Society B, 280, Article ID: 20130081. https://doi.org/10.1098/rspb.2013.0081 